\title{
CLASSICAL PHILOSOPHICAL FOUNDATIONS OF FUNDAMENTAL SCIENTIFIC RESEARCH' INSTITUTIONALIZATION IN COGNITIVE SOCIETY
}

\author{
Oleksandr Levchenko ${ }^{1}$, Al-Ghazali Ameen Saif Ali ${ }^{2}$
}

\begin{abstract}
The subject of publication is the theoretical generalization of the philosophical foundations of fundamental scientific research (FSR). The stages of institutionalization of attitude to the FSR are considered, from the stage of critical discussion of the conditions for obtaining true knowledge of the Hellenistic period to the developed system of teaching about the transcendental logic of Kant and Hegel's logical teaching about being, essence and concept in the context of fundamental scientific research. The methodology is based on generalization of the most radical points of view and approaches of representatives of different philosophical schools and research programs to clarify the essence and ways of FSR. The causes and gnoseological origins of the FSR scientific method change to the modern form of the method of verification toleration of scientific theories of post-positivism and metapositivism (Popper, Lakatos, Kuhn, Feyerabend) are described. As a result of the study, it was concluded that the period of radical rethinking of the classical paradigm of fundamental theoretical research, which is set out in the teachings of researchers of the ancient period, the New Time, classical German, Marxist philosophy, has started. Instead of the deterministic method of scientific thinking, the verification logic of substantiation of the process of generating new knowledge (line Descartes\&Pascal), the method of verification toleration/refutation of Popper is adopted by scientists. At the same time, the justification for the truth of the FSR is based on the development of Descartes' teachings about the method. The applied result of the practical application of the Popper's concept in the field of FSR implementation is a deliberately probabilized style of scientific cognition, the principle of verifying the intermediate interpretation of the truth, updating practical approaches to demarcation procedures, justifying the partial and permissible value of scientific theories as "points of invariability" in the continuum of continuous inaccuracy and uncertainty (Hume/Berkeley vs. Bacon/Newton line).
\end{abstract}

Key words: fundamental science research, cognitive society, philosophical foundation of FSR, verification of science theories and knowledge.

JEL Classification: A11, 120, 123

\section{Introduction}

Accelerated and emphasized saturation with hightech elements of dominant technological processes, further improvement of the level and quality of collective and personal well-being of stakeholders of clustered innovatively oriented ecosystems is objectively associated with the transformation of the FSR from a kind of peripheral elitist activity into a main focus of development of postmodern cognitive society.

The subject of publication is the theoretical generalization of the philosophical foundations of FSR. The stages of institutionalization of attitude to the FSR are considered, from the stage of critical

\footnotetext{
Corresponding author:

${ }^{1}$ Central Ukrainian National Technical University, Ukraine.

E-mail: omlevchenko@ukr.net

ORCID: https://orcid.org/0000-0001-5452-7420

${ }^{2}$ Central Ukrainian National Technical University, Ukraine.

E-mail: abosultan711@gmail.com

ORCID: https://orcid.org/0000-0002-4524-7360
}

discussion of the conditions for obtaining true knowledge of the Hellenistic period to the developed system of teaching about the transcendental logic of Kant and Hegel's logical teaching about being, essence and concept in the context of fundamental scientific research.

\section{Methodology}

The research is based on generalization the most radical points of view and approaches of representatives of different philosophical schools and research programs to clarify the essence and ways of fundamental scientific research (FSR). The period of generalizations 
includes a period of time from ancient times to the middle of the twentieth century and consistently represents the views of the authors of the Hellenism era, the New Time, the heyday of classical philosophy to the era of empiriocritism and the Vienna School of Neopositivism. The scientific origins of the emergence of modern theories of critical rationalism as a general theory of the FSR, acceleration and dynamics of growth not subject to inflation of scientific knowledge, critical empirism as a stage of development of logical empirism are investigated. The causes and gnoseological origins of the FSR scientific method change to the modern form of the method of verification toleration of scientific theories of post-positivism and metapositionivism (Popper, Lakatos, Kuhn, Feyerabend) are described.

\section{Results}

The ancient period of FSR is associated with the introduction of the practice of critical discussion of conditions for obtaining true knowledge with the central problem of passive relation between compulsory, stable, objective knowledge (in compulsory unity with its subject) and problematic knowledge, including correct, as well as illusory, false, unreliable, truth and delusion. The absence of a fundamental logical contrast between the subject and the object of cognitive activity is associated with the fact that the theory of cognition (TC) exists for ancient thinkers only in connection with the task of constructing a picture of space.

Basic understanding of the essence of knowledge was state by $\Pi \lambda \dot{\alpha} \tau \omega \nu$ (Plato) (427/429-347 p. BC)

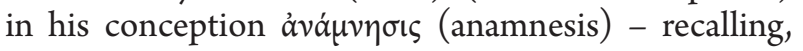
ascent to knowledge, wisdom, true knowledge of the world of ideas by an intelligent part of the soul when perceiving objects of the sensual world, which differs from $0 \pi \circ \mu \nu \eta \sigma \iota s$ (hypommnesis) - a simple mention, reflection, an voice of truth in the soul embodied in the human body, written recording of external impressions (Serezhnikov, 1936). The knowledge of the "visible" ( $\varepsilon \tilde{\delta} \delta \varsigma \varsigma)$, as opposed to the idea itself ( $(\delta \varepsilon \dot{\varepsilon} \alpha)$, is a form of spiritual and cognitive reflection of the natural connections-relations of the outside world, which is aimed at its transformation, is interpreted $\Pi \lambda \dot{\alpha} \tau \omega \nu$ as

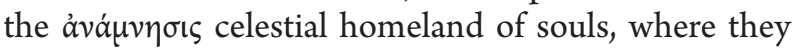
are perceive any of them directly, face to face, while after resettlement in the rough earthly reality they remained

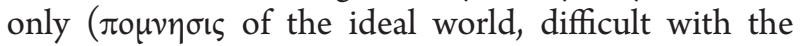
vं $㇒ \dot{\theta} \theta \sigma ı \varsigma$ darkness and gravity of matter.

The doctrine of the idea provides the principle

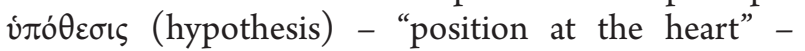
related to the "meaningful prerequisite", "basis", "basic principle", "foundation", the basis of the meaningful existence of the thing and its structure (Plato, 1965). The put forward concept included the need for a certain practice of the soul, its care for itself, the use of "memory without a sign", the gathering in indivisive unity from the scattered world of sensations, its trains and entertainment, its direct presence in the truth, its improvement and accumulation. Such actions allow to solve the paradox of the transition from ignorance to knowledge, and the solution was that in reality there is no absolute ignorance, there is only a deceptive ignorance of oblivion, which is ready to wake up to memory or roll down to even greater ignorance and oblivion. Due to the attraction of memory, there is an initial retreat from direct discretion, it becomes the key not to the imaginary, but to the real ignorance of the truth, a retreat from pure and impurity-free knowledge.

Dialectics for $\Pi \lambda \dot{\alpha} \tau \omega \nu$ consists in the discretion of the very principle of sciences, "giving and demanding content" for sensual things, separating one into disparate, building disparate to a single, structural representation of the whole as a single-separate plurality, overcoming any dualism. Pure, true knowledge is the result of a dialogical search for $\alpha \rho \chi \eta$, the principle of every thing, in which everything possible, is provided, so that $\alpha \rho \chi \eta \dot{~}$ acts as a semantic method of existence, contains the whole plan of this latter structurally and one-separately. In the $\Pi \lambda \dot{\alpha} \tau \omega \nu$ of the book, dialectic - the doctrine of unity of opposites, the search for the principle of each thing, obtaining true knowledge about it - can be presented as follows:

- dialectics, entering the sphere of confusing things, dismembers them so that each of them receives its own content - i $\delta \dot{\varepsilon} \alpha$;

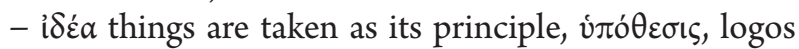
( $\lambda$ óros) subordination to the general subordination of private entities to it, the law (vouós), which leads from scattered sensuality to an orderly idea and vice versa; dialectics consists in establishing imaginary grounds, a priori categories, forms representing an objective and meaningful reflection of the real reality of the existence of things;

- chain "logic - idea - hypothesis - basis" dialectics perceives as the boundary of sensual and material formation of things, which in compressed form contains its "deployment", acts as a plan, structure, content of existence;

- dialectics as the "broom of sciences" is both discourse (consists in logical dismemberment) and intuitive (consists in the merger of the content), cognitive teaching about indivisible integrity, synthesis of the boundaries of discrete (immobile) parts of a particular thing and the unlimitedness of its holistic idea, unlike other sciences that only "dream", collectively sees the essence of things "in reality";

- dialectics is not just the ability to have a conversation, ask and answer, among the sad disputes to find and practically apply the truth, how much the ability to

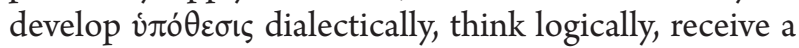
searchable object in a dismembered, unicorn, structural form, is to transform knowledge in the most true way that everything else becomes "secondary and later". 
The method of dialogueal cognition of the of

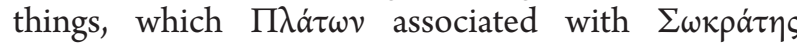
(470/469-399 BC) (Politis, 2006), implemented in the process of resolving $\pi \alpha \rho a ́ \delta$ o $\xi_{\circ} \varsigma$ - a paradox, a contradiction that arises in theory, provided that it adheres to the logical correctness of the reasoning.

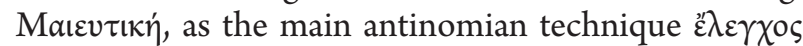
(élenchos, test), $\sum \omega \kappa \rho \alpha \dot{\tau} \eta \varsigma$ provides for the ironic

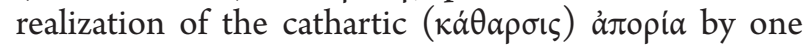
of the parties to the dialogue in order to implement the zetic ( $\left.\zeta H_{\eta} \eta \sigma, \sigma\right)$ á $\pi$ opía, a dichothomy that results in the "birth" of truth by the other party of (scientific) dialogue.

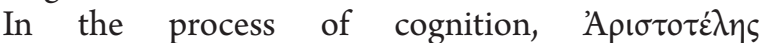
(384-322 BC) distinguishes different degrees: practical skills, skill, action according to the pattern ( $\tau \dot{\varepsilon} \chi \nu \eta)$; quick and effective situational thinking ( $\varphi \rho o ́ v \eta \sigma \varsigma)$ ) about what contributes to actions about things that are good or bad for humans; science; wisdom ( o $\varphi^{\prime} \alpha$ ) - intelligent ability in creativity, a special idea or embodied knowledge about the causes and sources, the degree of knowledge of the world around us in the context of the desire for deepening as a specific property of human intelligence; mind (voũs) productive force of knowledge, generalization of all meaningful, intelligent and mental patterns that prevail in space and man. In the doctrine of fundamental knowledge, he distinguishes "dialectic" and "apodictic" varieties. The first is related to the sphere of isostenic judgments, which may be one or the other. Apodictic knowledge is true. At the same time, experience is not the last instance to justify higher links of science. Only the mind directly sees the higher references and their truth. At the same time, the general principles of contemplative knowledge are not born to humans, although they are potentially in the form of an opportunity to be acquired as a result of human's mental activity. In order to truly acquire them, one should gather facts, direct an opinion to them, and thus invoke the process of mental contemplation of higher truths or references for such contemplation, scientific definition of the subject of research. A complete definition of the essence of a thing can only be achieved by combining deduction and induction: first, knowledge of each individual property must be acquired in an experience way; secondly, the belief that this trait is essential must be proved by the condition of a special form - categorical syllogism (Lukasiewicz, 1959) of its historically first, logical theory of deduction. The three terms of syllogism - four reasons (material, formal, action, final), consequence and carrier of the cause -

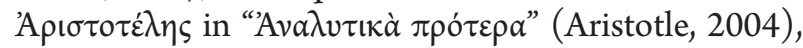

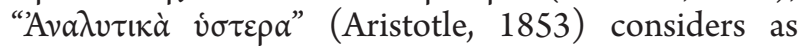
the central part of the logical doctrine of "Organon", and the basic principle of syllogism considers the relationship between a family, a species and a unitary thing. The systematized unity of the logical theories of

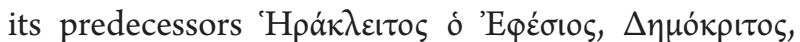
$\sum \omega \kappa \rho \dot{\alpha} \tau \eta \varsigma, \Pi \lambda \dot{\alpha} \tau \omega \nu$ - was supplemented by the theories

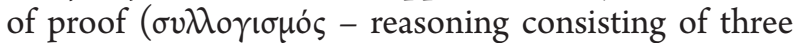
simple at attribute expresses - two founders (larger and smaller) and one conclusion, figures and modusas),

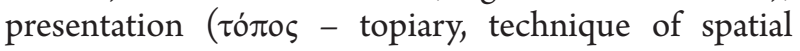
organization of thinking and understanding, as well as organized on the basis of thought space), etc. For the first time in the history of thinking, scientists were classified forms of movement - the emergence, destruction, qualitative change, increase, decrease, movement. Since there is no single predicate, a holistic concept to which all other concepts can be summarized,

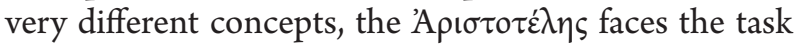
of listing all the higher genera - the categories to which

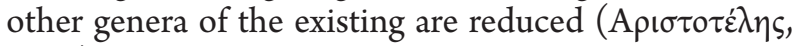
2011). The list of these highest concepts, which use the tools of knowledge of the deep essence of things, includes the essence, quantity, quality, attitude, place, time, position, inherentness, action and subject to it.

Development of the theory of cognition in the new time (Yeshchenko, Koval, Tsvirko, 2019; Baklanova, Petrova, Koval, 2020), which was associated with the search for absolutely reliable knowledge, updating the paradigm of the FSR during the 17th-18th centuries, was explained by the fact that at that time the first roles were the need to limit the substantiation of the entire set of accumulated knowledge, their assessment according to the degree of truth.

Francis Bacon (1561-1626), who implements a handcrafted plan "Great Instauration" ("Instauratio Magna”), divides all its varieties according to the three abilities that are inherent in the human mind. Memory contributes to the realization of history, imagination allows you to engage in poetry, mental abilities are the source of philosophy. Nature is learned directly, God is learned through nature, man is learned through reflection. In addition to these partial sciences, Bacon refers to the field of the desired "first philosophy" (desiderata), which has an attitude to all concepts suitable for use in all fields of knowledge. The most important at the same time is the science of nature, which is also divided into theoretical, which explores the causes (physics and metaphysics), and practical, which brings results (mechanics that on a practical level correspond to physics and natural magic - metaphysics). The logical method of "true guidance", interpretation of nature, discoveries and inventions based on a systematic experiment, the scientist contrasts with deductions (unprofitable for obtaining new truths), as well as primitive induction (simple list of random signs). Scientist considers the true reasons for the "delusion of reason" is "ghosts" of the human race (distorted reflection of things due to the fact that man mixes with their own nature); caves (individual characteristics of man); market (misunderstanding of words); theater (false pupils who lure a person like theatrical performances). 
In "New Organon" (Bacon, 1620) there is a distinction between experiments on "fruiting" and "light-bearing" experiments. The former rush to the nearest results and ignore the realization of causes as the only source of true power of man. "Light-bearing" experiments, which do not benefit themselves, contribute to the discovery of causes / axioms, can become a source of new practical discoveries /

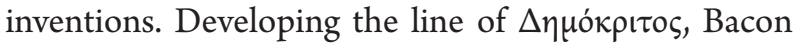
tries to find in the things of others, materialistic, full internal activity of the world its atomic structure in order to solve the main task of science - to "change the "nature" of bodies and "promote the well-being of people". The scientist is convinced that matter "seems to smile with its ethical-sensual brilliance to all

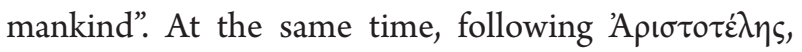
inductively exploring the fundamental "forms" entities, bases, laws of formation of this property, Bacon carries out their construction to a certain configuration and movement of small material particles that form the body. The researcher distinguishes between 19 qualitatively different varieties of the movement of matter, thereby proving that the specific task of true induction is to find forms that "help" the mind. The above-mentioned purpose should be to serve the tables of presence, absence and degrees proposed by him, which determine the specific ways of taking into account the studied qualities in certain subjects of this class. Comparison of tables should contribute to the establishment of just such a feature, which is necessary associated with the quality under study, causes it, makes its form. Filling tables, picking up examples, knowing the mass of facts Bacon considered the most important task of modern science. Conclusion on the basis of the proposed methodology "Natural and Experimental History" was to serve as a separate part of the grand plan of the "Great Instauration" of sciences.

Renatus Cartesius, Descartes (1596-1650) together with Bacon sees the ultimate goal of FSR in human domination over the forces of nature, discovery and invention of technical means, knowledge of causes and actions, improvement of human nature itself. Without finding a universal method, the initial thesis, Descartes questions the truth of the generally accepted knowledge covering all its species. Dual rationalism based on the ambivalence of ideal and material, as well as protracted (le extensa) and thinking (res cogitans) substances, initiated by the scientist, its mechanics as a counterweight to animism and vitalism (Thomas Hobbes line (1588-1679) - Julien Offray de La Mettrie (1709-1751) - Paul-Henri Thiry, baron d'Holbach

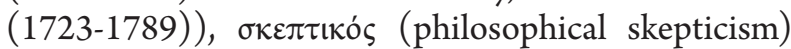
(line of Пú $\rho \omega v$ (360-275 BC) - Michel de Montaigne (1533-1592) - Pierre Charron (1541-1603)), formed under the influence of observation of the logical the nature of mathematical knowledge as absolutely reliable, comprehensive and necessary, one that flows from the nature of the intellect itself. The set of these considerations, combined with the search for perfect accuracy in the process of forming an unshakable, unquestionable truth, provided for the possibility and necessity of overcoming certain false qualities and signs of empiricism (gives rise to the truth approximate and relative) and, at the same time, mysticism (boasts super-sense, super-irrational knowledge). The exclusive role in the process of cognition was given to deduction - reasoning, which relies on absolutely reliable initial provisions - axioms and consists of a chain of reliable logical conclusions (Koval et al., 2019). Directly obvious initial provisions - intuition have advantages over deduction considerations. Therefore, armed with probable means of thinking - intuition and deduction, the mind is able to achieve complete authenticity in all areas of knowledge, provided that it will use the true method. According to Descartes, the true or rationalistic method of scientific research must meet four requirements:

- firstly, to assume only such provisions as true, which are clear and obvious, that is, do not cause doubts (si clairement et si distinction);

- secondly, dismemberment of each complex problem (difficultes) into constituent parts;

- thirdly, methodical transition (pensées) from known and proven to unknown and unprodexperied;

- fourthly, no omissions in logical research chains, compilation of lists and reviews (revues) (Descartes, 2018).

Descartes resents syllogism as a source of new knowledge, considers it a means of organizing truths already known otherwise. The combination of previously obtained truths in the researcher's mind is not seen as a mechanistic condition, but is a synthesis, a priori act of creativity. At the same time, in the process of developing a scientific picture of the world, the "temporary dwelling" for the researcher should be morality, for which their rules are displayed (maximes): obey the laws and customs in which he was brought up; be constant (constamment) in your decision and not wander from side to side; change yourself, not the "order of the world" (l'órdre du monde).

The translational institutional formation of the FSR in the philosophy of the New Time is associated with the overcoming of שפינוזה •ברוך (Benedictus de Spinoza) (1632-1677) cartesian dualism of material and spiritual substances (Spinoza, 1957). According to this doctrine, the dependence of a person's thinking on his bodily condition is manifested at the stage of sensory knowledge. In the course of the latter, the first kind of knowledge is formed - discretion (opinio), which can be contrasted with understanding (intellectio), not only as a single source of reliable truths, but as the second kind of cognition consisting of awareness (ratio) and intelligence (intellectus). Achieving adequate truths is only possible at this stage. The third kind of cognition 
is intuition (intuitio), a real foundation of reliable knowledge. This kind of knowledge שפינוזה-ברוך associates with the teachings of mystical pantheism about "inner light" and Descartes' teachings about the axioms of the "clear and expressive mind" as the foundation of all knowledge. Intuition is intellectual, so it ensures the knowledge of things in terms of eternity, as a necessary moduls of a single substance.

Representative of English empiricism John Locke (1632-1704) argued that the material of knowledge for the soul (tabula rasa) are simple ideas (sensations and reflections), all of which come from a sensational, personal sensual experience (Locke, 2002). Complex ideas have the following design: a) the concepts/first qualities contained in things consist of simple through their comparison, combination, abstraction, measured quantitatively, exist objectively; b) secondary qualities are not contained in the items attached to the idea of the substance due to subjective perceptions; c) the relationship between different ideas; d) modus, mental designs. The main property of the mind is the ability to test ideas for quality. Distinguishing between three elements of cognition - intuitive, demonstrative, sensational - confidence in knowledge is recognized as the highest for the first, the lowest - for the latter. The limitations of knowledge are compensated by the possibility of providence by which God rewarded man.

Gottfried Wilhelm von Leibniz (1646-1716) emphasized that rational foundations of the FSR should rely on the methodology, the most important requirements of which were the versatility and severity of philosophical discretions (Leibniz, 2017). The innate ability of the mind to know ideas and truths is given not in finished form, but only as a "predisposition", a deposit. In addition, unlike Locke, Leibniz acknowledged the essential importance of probabilistic knowledge, introduced division by a special role in knowledge into the necessary "truths of the mind" and random "truths of fact". A priori, independent of sensory experience, the principles of being, the scientist declared:

1) inconsistency of any possible/imaginable existence (law of contradiction);

2) logical primate of the possible before the actual/ existing one; possibility of infinite set of noncontradicting "worlds";

3) sufficient justification of the fact that this particular world exists, and not any other of the possible events, that this event takes place, and not another (the law of sufficient justification);

4) optimality (completeness) of this world as a sufficient justification for its existence.

The physical world by Leibniz considered the unfinished sensual reflection of the true world of monads - indiviolable elements of being, which are among themselves in a relationship of "pre-established harmony”, as a phenomenon of a person who learns the objective world. But, given the fact that physical phenomena are generated by real, the scientist considered the first "well-grounded" means of space, matter, time, mass, movement, causality, interaction, as they were understood by physicists and mechanics of that time. In logic, Leibniz developed the doctrine of analysis and synthesis, formulated the law of identity (principum identitatis) - one of the basic laws of thinking as a cognitive activity, which expresses the need to allocate each subject of thought in such a way that it can be operated as identical to itself in the processes of thinking, defined by the permanence of meanings of words.

Julien Offray de La Mettrie (1709-1751) denied dualism and proved the existence of only one material substance, primitive and lifelong, which constantly changes the forms of its existence. La Mettrie's materialism was to assert that the ability to feel, remember, and think does not contain signs of a supernatural and mystical, simple property of the human body. If the mind accumulates knowledge, for which nature has created all the conditions, then thanks to their brain is filled with ideas. The aggressive denial of Descartes' dualism and John Locke's idealistic provisions about the inner soul experience, reflection, embodied La Mettrie in anti-agnosticism, material sensualism, radically defending the view that feelings are not only images of objects, but also a criterion of truth (La Mettrie \& Hunauld, 2018). For the development of ideas FSR important are the ethical views of the scientist, as well as his utilitarianism. Decisive role in the development of society, he attributes enlightenment, conscious activity of individual prominent personalities, denies the existence of unchanging absolute moral values, protects the ideas of hedonism and Eudemonism in their balanced, rational understanding. His aesthetic concept is directed against austerity, the instillation of personality rights.

The subject of research of peculiarities of functioning of the FSR sphere by the founder of classical German philosophy Immanuel Kant (1724-1804) during the "precritical" (until 1770) period of its activity was the possibility of contemplative knowledge of things as they exist on their own. It was in the discourse of scientific exploration of this period regarding the development of nature that it substantiated the cosmos hypothesis about the formation of a planetary system from the original "nebula" (Kant, 2018), a diffuse substance with a gradual transformation to the current state in accordance with the laws discovered by Isaak Newton, which, according to Friedrich Engels (1820-1895), “... shaken by the idea that nature has no history in time..” (Marx \& Engels, 1960). Immanuel Kant's most significant scientific achievement was the substantiation of the worldview of the idea of development in inorganic and organic nature, which was later extended to special sections of natural 
sciences with the assistance of Johann Gottfried Herder (1744-1803) and Friedrich Wilhelm Joseph Schelling (1755-1854). In philosophical writings, the scientist moved away from the previously declared rationalistic views, according to which the real connection between the two facts can be derived from the logical connection of two concepts, which became the basis for the transition from the "precritical" period to the works of the critical.

The peculiarity of the critical period in terms of the formation of postulates of FSR development was the development of the author's line for obtaining true knowledge. The originality of Immanuel Kant's gnoseological position was that he finds a compromise between empirics (only experience can be a source of comprehensive and necessary knowledge) and rationalists (only the mind can be the source of comprehensive and necessary knowledge). The scientist claims that the source of true knowledge is independent of experience and preceding it a priori forms of sensuality and intelligence. Since, he has criticized the study of boundaries to which the possibilities of the mind are stretched, as well as other possibilities and forms of cognition. The scholasticism of the author's approach is that the essence - "the thing in itself" - cannot be given in the experience. Only phenomena - "things for us" that exist regardless of feelings, perceptions and forms of prudent thinking are available to knowledge. Entities affect our senses, affificate (Affizierung) sensations. External affixing (affection externa), contemplation is associated with sensuality, which "gives" us objects, as well as receptiveness, as a result, contrasts with the spontaneity of discretion. Internal affiliation (affection interne) is manifested in the fact that people from the inside are influenced by themselves as intelligent beings, who, moreover, know themselves only as a phenomenon - non-essence.

Direct to understanding the essence of the FSR has the logical teaching of Kant, which distinguishes between two different varieties of logic:

- accidental, general (allgemeine Logik), capable of giving objective comprehensive and reliable, but formal knowledge within the experience of the phenomenon of the phenomenon "things for us", explores the relationship of different concepts, judgments and conditions of forms, without distracting from the question of what they think;

- transcendental (transzendentale Logik), which differently weighs the forms of thinking and their competence depending on the direction on the subject, designed to compare the essence of "the thing within itself", which is beyond experience, a creative means of obtaining contradictory knowledge, which in case of an attempt to confirm the theoretical reliability with the need falls into contradictions, because it explores in the forms of thinking what gives the knowledge of an a priori nature, operates with the peculiarities of synthesis in the third category of the two previous opposing categories within each of their four categories - quantity (the only - set - wholeness), quality (reality - denial - limitations), attitude (substance - reason - interaction) and modality (possibility - reality - necessity) (Kant, 1994; Kant, 2000).

The reflection of objective characteristics of reality in the consciousness is manifested in the form of formulated judgments - the relationship between concepts in the analytical (does not give new, but only reveals in the predication the knowledge already contained in its subject) or synthetic (arises from the combination of knowledge contained in the predication with the knowledge contained in the subject) varieties. In turn, synthetic knowledge is divided into a posterior (the predicate's connection with the subject is based on experience) and a priori (the relationship between the subject and the predicate is thought as a predicate experience and does not depend on it). Based only in the a priori knowledge of the relationship of concepts can be universal and unconditionally necessary, Kant formulated questions about the sources and boundaries of reliable knowledge as a question about the possibilities of a priori synthetic judgments in each of its important varieties for the author (mathematics, theoretical natural science, metaphysicism). Solving the main issues of "Critics of the pure mind" is seen by their author in the study of the peculiarities of the use of a priori forms of cognition: sensuality as a capacity for sensation ("Transcendental Aesthetics"); prudence as the ability to concepts and judgments of the special as subordinate to the general ("Transcendental Logic"); the mind as a conditioned approach to the formulation of ideas as concepts of unconditional integrity of all conditioned phenomena ("Transcendental Dialectics") (Kant, 2000). Transcendental everything that lies on the other side of any possible experience is accepted, otherwise it is beyond the control even for the transcendental.

For real knowledge to arise, it is necessary to synthesize sensual contemplation with categories of discretion. The highest condition for the synthesis of the variety of sense content and the prudent forms covered by this content is the unity of our consciousness, the a priori "unity of transcendental apperception". Another link between sensory contemplation and discretion is the "productive power of imagination". The combination of these conditions makes it possible to scientific knowledge, which has an objective meaning, that is, logical signs of generality and necessity. Regardless of the peculiarities of the ratio of objects and phenomena to each other, scientific knowledge can be carried out only if the discretion thinks them, subject to three higher fundamentals of knowledge - the law of conservation of the substance; law of causality and the law of interaction 
of substances. These general and necessary laws do not belong to the nature that exists regardless of them, but only to the mind as the highest a priori laws of communication of all that discretion can think of. Thus, consciousness itself builds an object - not in the understanding of the real origin of its existence, but in what gives the recognizable, unknown in its essence the form under which it can only and can be understood a form of general and necessary knowledge. That is, the things of nature are consistent with the forms of the mind, and not vice versa. The mind finds and is able to find in nature only what he has invested in it and regardless of it, that is, general and necessary forms of experience. Therefore, nature, as a subject of knowledge, is built by consciousness. The subject of any science that is built by consciousness on the part of the logical form of knowledge is subjective idealism, and therefore agnostic things are how they exist on their own. However, while Kant does not put a boundary on empirical knowledge of things, claiming that "... observation and analysis penetrate into the insides of nature, and it is not known how far we will go along the way over time", the "thing in ourselves" will always remain on the other side of any possible experience for us.

In full accordance with the categories of a priori judgments, the objective idealist Kant develops sketches of real natural sciences: "foronomy" - about spatial changes; "dynamics" - about moving forces; "mechanics" - the doctrine of the laws of interaction of moving bodies; "phenomenology" - about the possibility, reality and necessity of movement depending on the differences in the way of representation.

In the process of exploring the third possibility of cognition in the field of formulation of a priori theoretical judgments in metaphysics, i.e. theoretical philosophy, Kant considers the mind as a conditioned ability, leading to the emergence of ideas - concepts of unconditional, subjects of which cannot be perceived by feelings in experience. Trying to find unconditional integrity, unity of conditioned phenomena, the mind must form three ideas: the idea of the soul as the unconditional integrity of all conditioned mental phenomena (the subject of psychology); the idea of the world as an unconditional integrity of an infinite series of causal phenomena (the subject of cosmology); the idea of God as an unconditional cause of all conditioned phenomena (the subject of teleology). Kant's guess about the need for antinomy - opposite and at the same time logically evidence-based ideas about objects in the human sense, led to further recognition that they express not only the subjective, but also objective dialectic of thinking, as well as being.

The founding ideas of Georg Wilhelm Friedrich Hegel, which may be involved in clarifying the deep essence of the FSR, are set out in his "Phenomenology of the Spirit" (Hegel, 2019). In the paper, the author argues in the opinion that the gender of philosophical knowledge has the form of a translational movement of consciousness from the first direct contrast between it and the subject, to absolute knowledge. Along the way, there is a overcoming distance from direct sensual authenticity to philosophical knowledge.

The first section of the work examines the categories of consciousness, self-consciousness, mind, and considers the movement of individual consciousness from sensual authenticity to knowledge of reasonable reality. In the first phase (meaningal, empirical stage of cognition), consciousness knows neither its nature nor the essence of the subject. In the second phase, consciousness cools down its own social nature and rises to an understanding of the content of history as a collective activity of individuals. In the third, last phase, the spirit, giving a retrospective look at all the stages of history, rises to absolute knowledge.

The central category of "Spirit Phenomenology" is alienation (Entausserung, Entfremdung), which Hegel understands as the emergence of all subjectivity from the spirit, firstly, the origin of the absolute spirit of nature and society; secondly, any complex relationship between the subject and the object, expedient activity on the disposal of human essential forces; thirdly, people's distorted perception of products of their own activities, the idea of them as hostile, alien forces living on their own, rule over them.

The analysis of "phenomenological knowledge", "what appears", becomes the basis for Hegel to assert - the most profound idea of all things is an absolute idea that develops on the principle of the Johann Gottlieb Fichte triad "thesis - antithesis synthesis" (Oizerman, 1962) in three main forms of a holistic system: in the form of pure logical entities $(\operatorname{logic})$; in the form of ino-existence of the idea nature (philosophy of nature); in various forms of a particular spirit (philosophy of spirit).

The subject of logic, which makes up the basis, the essence of all activities, is its own absolute idea, which unfolds its moments in the form of categories. Pure logical entities are a demiurge, a primary substance in relation to reality.Logical categories are comprehensively related, one that goes into each other, so in the dialectic development of categories the real dialectic of "things" is "guessed".

Logical doctrine, the main concepts of which can be the basis of FSR in cognitive society, Hegel lays out the doctrine of being, about the essence and concepts (Hegel, 1929; Hegel, 1934; Hegel, 1937).

Analysis of problems of cognition theory regarding the features of the FSR in the philosophy of the twentieth century is characterized by a number of features. Marxist current of philosophy one of its sources declared classical German.

The fundamental difference between dialectic materialism (Marx-Engels line) from gnoseological idealism in matters of development of the theory of 
cognition, which is directly related to the organization of the FSR, is observed in the following elements:

- the material world is recognizable, the objective reality exists outside and regardless of consciousness, in general the world is gnostic;

- the dialectic materialism considers ontological and gnoseological aspects of philosophical problems in their unity - dialectics, logic and theory of cognition are the only ones;

- the essence and nature of knowledge are social in nature and cannot be understood in isolation from subject-practical activities;

- the confrontation to idealistic and metaphysically interpreted sensationalism is declared, the irredience of real cognition to simple summation or mechanistic transformation of sensational data is emphasized;

- empirical data operated by science are formed in the process of using theoretical provisions to describe the content of sensory experience and involves a number of theoretical idealizations that should simultaneously be understood as a moment of active practical sensual and subjective activity;

- theoretical thinking is guided by the reproduction of the object of cognition by ascent techniques from abstract to specific, inextricably linked with the principles of unity of logical and historical, analysis and synthesis;

- categories and laws of materialistic dialectics are not only forming of reflection of objective reality, but also methodological principles of scientific and theoretical activity;

- cognitive process is considered not so much in the form in which the individual is carried out in the head, so much in the form of a socio-historical process of knowledge development;

- use of the dialectical-materialistic principle of Historicism is combined with the recognition of the specific historical nature of the basics of knowledge, is a means of overcoming Gnoséological relativism, the development of the doctrine of the dialectic of absolute and relative truth;

- social practice acts as the basis, the purpose of knowledge, the criterion of truth;

- theory of cognition $\neq$ the theory of reflection, the process of cognition proceeds not in the form of passive monitoring from the outside of these objects, but in the form of a number of ideal actions organized into the system, operations that form some ideal objects that serve as a means for cognitive assimilation, reflection of the objective world;

- the process of human reflection is inextricably linked with the processes of material and ideal creativity; - theory of cognition is not metha-science, theoretical and cognitive interpreting of science begins where theoretical structures are interpreted in terms of correspondence of reality, truth, ability to grant the status of existence to used abstract objects, to evaluate as analytical or synthetic statements of this scientific sphere;

- gnoseological interpreting of specific scientific theories acts, on the one hand, as the application of general principles of cognition theory to the analysis of specific cases, on the other - as a kind of assimilation of new scientific results for clarification, sometimes viewing some common gnoseological postulates. Development may require a new gnoseological interpretation of scientific theories (Marx, 1955; Engels, 1955a; Engels, 1955b; Marx \& Engels, 1960a; Marx \& Engels, 1960b; Lenin, 1972).

\section{Discussion}

The current stage of formation of the foundations of the FSR implementation, on the one hand, is associated with a radical revision of the classical paradigm of fundamental theoretical research, which is set out in the teachings of researchers of the ancient period, the New Time, classical German, Marxist philosophy. Instead of deterministic method of scientific thinking, verification logic of substantiation of the process of generating new knowledge (line Descartes and Pascal), scientists adopt the method of verification toleration/refutation of Popper. The theoretical basis of Popper's teachings is (i) positivism (Saint-Simon, Comte, Mill, Spencer), (ii) empirical criticism (Mach, Avenarius, Pearson, Duhem), (iii) neopositivism (Vienna School, philosophy of logical analysis), (iv) post-positivism (Quine, Armstrong, Rorty, Feyerabend). At the same time, the justification for the truth of the FSR is based on the further rapid development of Descartes' classical teaching about the method. According to the position of this scientist, the analysis is used to discover the truth, and synthesis - to transmit it to others. The need to use clear rules to formulate definitions, axioms, conduct evidence, justify the research method in a narrow sense of the term remains unchanged. In addition, there is a further development of the method of searching for grammatical, logical and metaphysical arguments of evidence. Therefore, naturally, the continuation and development of the classical theoretical bases of the FSR implementation, at the same time, as an applied result of the practical application of post-positivist concepts in the field of FSR implementation, consciously probabilistic style of scientific cognition, the principle of verifying the intermediate interpretation of the truth, belonging of statements about it to empirical science and denying the suitability of the use of deterministic method of thinking, metaphysics, psychoanalysis and individual psychology to the procedure of demarcation, substantiation of partial and acceptable scientific value of theories as "inviolable points" in the continuum of continuous inaccuracy and uncertainty. 


\section{Conclusion}

The prospects for further exploration are seen in an in-depth study of the possibilities of deploying creative potential, which are created using modern approaches to the implementation of the FSR. The metapositivist stage of FSR institutionalization is realized in the field of neo-Kantian "pure gnoseology" and its recognition of philosophy with the theory of cognition (Bogomolov, 1969); critics of this approach from the camp of transcendental phenomenologistsontologists (Husserl, 1994), empirical psychologists (Frank, 2007); representatives of the conglomerate of idealistic empiricalism and ontology - empirical critics, English neo-realists, "sensibulists", American neo-realists (James \& Russel, 2010; Bogomolov, 1962); linguistic analysts (Gryaznova, 1993); adepts of the line "positivism (Narsky, 1961) - neopositivism of scenic logical positivism (Ayer, 1959; Achinstein \& Barker, 1969) - linguistic philosophy (Charlesworth, 1959) - logical pragmatism of the change of truth (instrumentalism, fallibism, anti-realism, radical empirism, verifiationism) (James \& Russel, 2010; Dewey, 2001) - post-positivism" (Panin, 1981; Carnap, 1971), as well as the implementation of applied theories of changing scientific paradigms and reproduction of competing theories (Popper, Lakatos, Kuhn, Feyerabend).

\section{Acknowledgement}

The paper was supported by Erasmus+ Project № 609944-EPP-1-2019-1-LT-EPPKA2-CBHE-JP "Enhancing Capacity of Universities to Initiate and to Participate in Clusters Development on Innovation and Sustainability Principles"

\section{References:}

Achinstein, P., \& Barker, S. F. (1969). The Legacy of Logical Positivism: Studies in the Philosophy of Science. Johns Hopkins Press, 300 p.

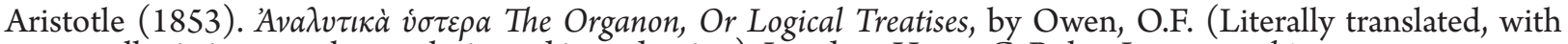
notes, syllogistic examples, analysis, and introduction). London: Henry G. Bohn. Internet archive.

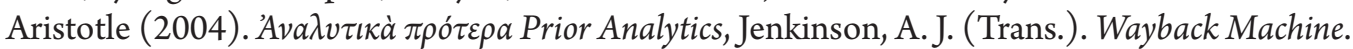

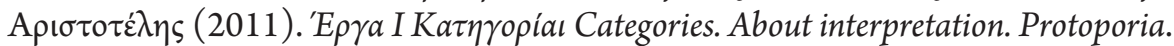

Ayer, A. (Ed.) (1959). Logical positivism. issuu.com.

Bacon, F. (1620). Novum Organum The New Organon or True Directions Concerning the Interpretation of Nature. metaphysicspirit.com.

Bogomolov, A. S. (1962). Philosophy of Anglo-American Neorealism. Moscow: Izd-vo Mosk. un-ta, 448 p.

Baklanova, O., Petrova, M., \& Koval, V. (2020). Institutional Transmission in Economic Development. Ikonomicheski Izsledvania, 29(1), 68-91.

Bogomolov, A.S. (1969). German bourgeois philosophy after 1865. Moscow: Izd-vo Mosk. un-ta, 448 p. (in Russian) Carnap, R. (1971). Philosophical Foundations of Physics. Introduction to the philosophy of science. Moscow: Progress, 390 p. (in Russian)

Charlesworth, M. J. (1959). Philosophy and Linguistic Analysis. Pittsburg: Duquesne University, 234 p.

Descartes, R. (2018). Discourse on the method. Moscow: Azbuka, 320 p.

Dewey, J. (2001). Reconstruction in Philosophy. Zanadvorov, M., Shikov, M. (Trans). Moscow: Logos, 94 p.

Engels, F. (1955). Anti-Duhring. in: Marx, K., Engels, F. Collected Works, 2nd ed., v. 20.

Engels, F. (1955). Dialectics of Nature", in: Marx, K., Engels, F. Collected Works, 2nd ed., v. 20.

Frank, F. (2007). Philosophy of Science: Communication between Science and Philosophy, ed. 2nd, Kursanov, G. A. (Trans.). Moscow: Izdatelstvo LK.

Gryaznova, A. F. (Ed.) (1993). Analytical philosophy: Selected texts. Moscow: Izd-vo MGU, 191 p.

Hegel, G. V. F. (1929). Collected Works. In 14 volumes. Vol. 1. Moscow: Gosudarstvennoye izdatelstvo politicheskoy literatury.

Hegel, G. V. F. (1934). Collected Works. In 14 volumes. Vol. 2. Moscow: Sotsekgiz.

Hegel, G. V. F. (1937). Collected Works. In 14 volumes. Vol. 5. Moscow: Sotsekgiz.

Hegel, G. W. F. (2019). Phenomenology of spirit, Tarashchuk, P. (Trans.). Kyiv: Folio, 476 p. (in Ukrainian)

Husserl, E. (1994). Philosophy as a strict science. Novocherkassk: Saguna, 357 p. (in Russian)

James, W., \& Russell, B. (2010). Introduction to Philosophy. Philosophy problems. Moscow: Republic, 318 p. (in Russian)

Kant, I. (1994). Critique of the ability to judge. Moscow: Iskusstvo, 367 p. (in Russian)

Kant, I. (2000). Critique of pure reason, Burkovsky, I. (Trans.). Kyiv: Universe, 504 p. (in Ukrainian)

Kant, I. (2018). Prolegomeny to every future metaphysics, which may appear as a science, Terletsky, V. (Trans.). Kharkiv: Folio, 288 p. (in Ukrainian)

Koval, V., Duginets, G., Plekhanova, O., Antonov, A., \& Petrova, M. (2019). On the supranational and national level of global value chain management. Entrepreneurship and Sustainability Issues, 6(4), 1922-1937. http://doi.org/10.9770/jesi.2019.6.4(27) 
La Mettrie, J. O. de, \& Hunauld, F. J. (2018). Histoire Naturell de Láme. Wentworth Press, Paris, 372 p.

Leibniz, G. V. (2017). Monadology, Bartusyak, P. (Trans.), Khoma, O. (Ed.).: Café Philosophique, Lviv. issuu. Available at: https://issuu.com/twtdt/docs/monadologie (accessed 12 September 2020).

Lenin, V. I. (1972). On the meaning of militant materialism. Moscow: Politizdat, 16 p. (in Russian)

Locke, J. (2002). Exploration of human understanding, Bordukova, N. (Trans.). In 4 books. Vol. 1. books.google.com. Available at: https://books.google.com/books?id=LvZJjAX1xAYC\&pg=PA5\&hl=uk\&source=gbs_selected_ pages\&cad (accessed 25 September 2020).

Lukasiewicz, J. (1959). Aristotelian syllogistics from the point of view of modern formal logic. Moscow: Izdatelstvo inostrannoy literatury, $312 \mathrm{p}$. (in Russian)

Marx, K. (1955). Theses on Feuerbach. in: Marx, K., Engels, F. Collected Works, 2nd ed., v. 3. www.marxists.org. Available at: https://www.marxists.org/russkij/marx/cw/t3.pdf (accessed 14 October 2020).

Marx, K., \& Engels, F. (1960). Works, 2nd ed., vol. 2. Moscow: Gosudarstvennoye izdatelstvo politicheskoy literatury, p. 143. (in Russian)

Narsky, I. S. (1961). Modern positivism. Moscow: AS SSSR, 423 p. (in Russian)

Oizerman, T. I. (1962). Fichte's philosophy. Moscow: Znaniye, 47 p. (in Russian)

Panin, A. V. (1981). Dialectical materialism and post-positivism (a critical analysis of some modern bourgeois concepts of science). Moscow: Izd-vo MGU, 240 p. (in Russian)

Plato (1965). Selected dialogues, Asmus, V. (Comp.); Egunov, A. (Ed. trans.); Soloviev, V. S. and others (Trans.). Moscow: Khudozhestvennaya literatura, 442 p. (in Russian)

Politis, V. (2006). “Aporia and Searching in Early Plato". Judson L. \& Karasmanis V. (Eds.). Remembering Socrates: Philosophical Essays. academia.edu

Serezhnikov, V. K. (1936). Plato. Theetetus, Serezhnikov, V.K. (Trans.), Vandek V.M. (Ed.). Sotsekgiz, MoskowLeningrad, $192 \mathrm{p}$.

Spinoza, B. (1957). Selected works: in 2 volumes, vol. 1. Moscow: Gospolitizdat, 631 p.

Yeshchenko, M., Koval, V., \& Tsvirko, O. (2019). Economic policy priorities of the income regulation. Espacios, $40(38), 11$. 